\title{
Energy demand \& prospect of geothermal energy as the solution of energy crisis of Bangladesh - an approach to green energy solution
}

\author{
A. S. M. Monjurul Hasan ${ }^{1, *}$, Md Habibullah ${ }^{1}$, Khaza Newaz Muhammad ${ }^{2}$, \\ Mohammad Walid Bin Siraj ${ }^{3}$, Md Ahsan Kabir ${ }^{1}$, A. S. M. Muhaiminul Hasan ${ }^{4}$ \\ ${ }^{1}$ Department of Electrical \& Electronic Engineering, IUT, Dhaka, Bangladesh \\ ${ }^{2}$ Department of Computer Science \& Engineering, IUT, Dhaka, Bangladesh \\ ${ }^{3}$ Department of Electrical \& Electronic Engineering, Fatih University, Turkey \\ ${ }^{4}$ Department of Electrical \& Electronic Engineering, AUST, Dhaka, Bangladesh \\ Email address: \\ a.s.m.monjurul.hasan@hotmail.com(A. S. M. M. Hasan)
}

\section{To cite this article:}

A. S. M. Monjurul Hasan, Md Habibullah, Khaza Newaz Muhammad, Mohammad Walid Bin Siraj, Md Ahsan Kabir, A. S. M. Muhaiminul Hasan. Energy Demand \& Prospect of Geothermal Energy as the Solution of Energy Crisis of Bangladesh - an Approach to Green Energy Solution. International Journal of Renewable and Sustainable Energy. Vol. 2, No. 6, 2013, pp. 217-221.

doi: $10.11648 /$ j.ijrse.20130206.15

\begin{abstract}
Bangladesh has among the lowest per capita energy (240 kg oil equivalents) consumption in the world and is severely dependent on additional environmentally friendly renewable energy resources in the future. Among the possible energy resources that could be explored is the potential geothermal energy in regions of higher geothermal gradients with favorable geo-tectonic setting and ideal petro-physical properties. A preliminary examination of bottom hole temperatures of a large number of on-shore wells spread over a vast area in the eastern part of the country, especially in Thakurgaon-Mymensingh-Sunamgonj-Sylhet through in the Bengal fore deep, strongly suggests that several other areas are of great interest for further studies in order to determine their geothermal energy potential. Bangladesh has witnessed a high demand for uninterrupted electricity due to rapid civilization in the last few years. Bangladesh needs now a reliable green energy sources as its power sector beset by many infrastructural problems (inefficient transmission system, very old power stations and cumbersome decision making process). Bangladesh has taken initiative to generate $25000 \mathrm{MW}$ electricity within 2021. In this regard, geothermal energy can be a viable and useful alternative and this paper proposes the prospects of its introduction to the power sector of Bangladesh. In this paper, a study is presented that shows the suitable locations in Bangladesh where geothermal power plants can be set up easily. Recently, the Ministry of Power, Energy and Mineral Resources has approved the establishment of the first ever geothermal power plant (200MW) in the country. A total of approximately $1000 \mathrm{MW}$ can be added into the energy grid of Bangladesh through geothermal power systems. The geothermal energy is green, indigenous, locally occurring and continuously available independent of climatic changes. It will help to reduce the huge oil bill that the country is facing now, provided the national planners give adequate attention and support for the development of geothermal energy at a rapid pace to reduce the severe electricity crisis in Bangladesh as other energy resources like peat, hydropower, nuclear, wind, tidal / waves are not significant at present.
\end{abstract}

Keywords: Geothermal Power System, Surface Temperature, Tectonic-Structural Region, Renewable Energy

\section{Introduction}

Bangladesh has the eighth largest world population of about 140 million in a small territory of 177,570 sq. km having the highest demographic density in this planet. About $80 \%$ of the rural population has very limited access to conventional energy sources like gas, coal and electricity.
They are mainly dependent on kerosene oil for lighting and biomass for cooking and for meeting other needs. The national energy policy is aimed at providing electricity to majority of rural people by 2020 . Presently, electricity is mainly generated by natural gas, the principal nonrenewable energy resource of the country. The daily production of gas is 757.5 MMSCFD per day of which presently $45 \%$ is consumed for power generation and $24 \%$ is used for 
production of fertilizer. Besides, domestic, commercial and industrial consumers use $26 \%$. The eastern half of the country has gas network and is the principal beneficiary. There are two distinct patterns of use of energy resources for power generation in the eastern and western zones-gas and hydropower resources in the eastern zone and oil (naphtha and diesel) and gas in the western zone while coal is yet to become a resource in near future. Among the renewable energy resources - wind power is almost non-existent. Waves, currents and tidal sources have little promise here. Only geothermal energy can emerge as the single largest and sustainable energy resources of Bangladesh especially in rural areas provided the abandoned dry on-shore wells drilled for petroleum exploration are utilized for the purpose.

\section{Geographical Information}

Bangladesh, a tropical to subtropical country, is located in the northeast part of South Asia between $20^{\circ} 34^{\prime}$ and $26^{\circ} 38^{\prime}$ North latitude and $88^{\circ} 01^{\prime}$ and $92^{\circ} 42^{\prime}$ East longitude. Bangladesh, with its 160 million people in a land mass of $147,570 \mathrm{~km} 2$, is one of the most densely populated countries in the world with $79 \%$ of its population living in rural areas. India surrounds the country on three sides (West, North and East), sharing $3715.18 \mathrm{~km}$ of a common border; Myanmar shares a mountainous border in the southeast; altogether this constitutes $93 \%$ of the borderline.

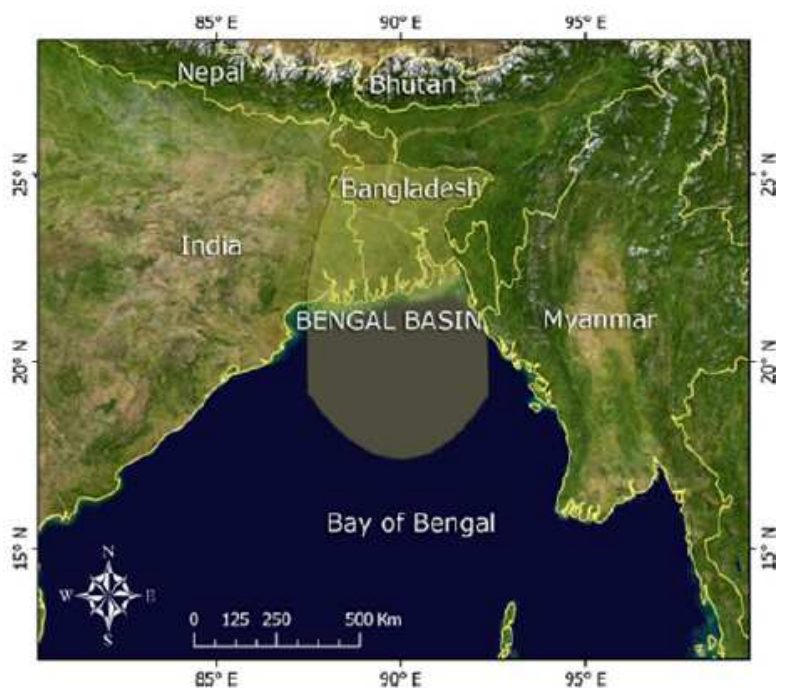

Figure 1. Location map of Bangladesh and surroundings

The Bay of Bengal is open to the south. The coastal zone of Bangladesh consists of about $710 \mathrm{~km}$ coastline, the largest patch of a natural mangrove forest shared with India and a long sea beach along the southeast coast. Three major types of landscapes are found in Bangladesh: floodplains (80\%), terraces $(8 \%)$, and hills (12\%). Excepting the eastern hilly region, almost all of the country lies in the active delta of three of the world's major rivers: the Ganges, the Brahmaputra, and the Meghna (GBM). The water ecosystem of the country comprises the tributaries and distributaries of these major rivers and numerous perennial and seasonal wetlands like haors, baors and beels. Huge amounts of rainfall runoff occur in the entire GBM catchments during the monsoon season (June-October), while in the dry period the country suffers from severe moisture.

\section{Energy Scenario of Bangladesh}

Bangladesh, considered a developing economy with a recorded GDP growth of above 5\% during the last few years, is one of the energy starved countries of the world. By some estimates, a GDP growth rate of $1-2 \%$ is forgone annually because of a shortage of energy and lower power generation. A major portion of energy is consumed for subsistence (e.g. cooking, lighting, heating, etc.) and only a small portion is used for economic growth (e.g. agriculture, industry, transport, commerce, etc.).

Table 1. Power Generation of Bangladesh

\begin{tabular}{|c|c|c|c|c|}
\hline $\begin{array}{l}\text { Responsible } \\
\text { Department }\end{array}$ & $\begin{array}{c}\text { Generation } \\
\text { Capacity } \\
\text { (MW) }\end{array}$ & Sub Total & Percentage & $\begin{array}{c}\text { Total } \\
\text { Generati } \\
\text { on } \\
\end{array}$ \\
\hline BPDB & 3600 & \multirow{4}{*}{ 4544MW } & & \multirow{10}{*}{$8315 \mathrm{MW}$} \\
\hline APSCL & 682 & & $55 \%$ of & \\
\hline EGCB & 210 & & generation & \\
\hline RPCL & 52 & & & \\
\hline IPPs & 1297 & \multirow{6}{*}{$3771 \mathrm{MW}$} & \multirow{6}{*}{$\begin{array}{c}45 \% \text { of } \\
\text { total } \\
\text { generation }\end{array}$} & \\
\hline SIPPs(BPDB) & 99 & & & \\
\hline $\begin{array}{c}15 y e a r s \\
\text { rental }\end{array}$ & 169 & & & \\
\hline $\begin{array}{c}3 / 5 \text { years } \\
\text { rental }\end{array}$ & 598 & & & \\
\hline Quick rental & 1382 & & & \\
\hline SIPPS(REB) & 226 & & & \\
\hline \multirow{2}{*}{$\begin{array}{c}\text { Furnace Oi } \\
1804 \\
21.70 \%\end{array}$} & $\begin{array}{c}\text { Diesel } \\
511 \\
6.15 \%\end{array}$ & $\begin{array}{c}\text { Coal } \\
200 \\
2.41 \%\end{array}$ & \multirow[t]{2}{*}{$\begin{array}{c}\text { Hydro } \\
220 \\
2.65 \%\end{array}$} & \\
\hline & & & & $\begin{array}{l}\text { ural Gas } \\
5580 \\
7.11 \%\end{array}$ \\
\hline
\end{tabular}

Total Generation Capacity: 8315 MW

$$
\text { aHydro aNaturalGas aFurnace Oil aDiesel } ₫ \text { Coal }
$$

Figure 2. Fuel type generation capacity according to Bangladesh Power Development Board (July, 2012)

From figure 2 we can see the fuel type generation of electricity. Natural gas plays the main role in Bangladesh for generating electricity. Recently furnace oil are been used massively in quick rental power plants. 


\section{Renewable Energy Scenario of Bangladesh}

Efficient utilization of renewable energy resources in Bangladesh has yet to obtain commercial dimensions and cannot serve as an alternative to conventional energy resources. However, they can serve to supplement the long term energy needs of Bangladesh to a significant level. Harnessing these resources appears to be a promising solution for improving the quality of life of rural villagers. Categories of renewable energy that are being used in limited ways in the country are hydro-, solar and wind power, bio-gas, and biomass such as wood, rice husks, etc. The present share of renewable energy is around $6 \%$. At present, the national capacity of renewable energy based power, excepting hydro-power, is approx. $50 \mathrm{MW}$ as shown in Table 2. Micro-hydro and mini-hydro, however, have limited potential in Bangladesh. Considering the fuel crisis, and exploring new, safe, and sustainable energy resources, the government has taken various steps to promote energy conservation and the use of renewable sources. Government of Bangladesh declared the Renewable Energy Policy, in effect since 2009 (MEMR, 2008). According to this policy, the government is committed to facilitating both public and private sector investment in renewable energy projects to scale up contributions of existing renewable energy based electricity production.

Table 2. Renewable Energy Scenario of Bangladesh

\begin{tabular}{lc}
\hline Category & Generation \\
\hline SHS $45 \mathrm{MW}$ & $45 \mathrm{MW}$ \\
Other solar PV applications & $1 \mathrm{MW}$ \\
Wind Energy & $2 \mathrm{MW}$ \\
Biomass based electricity & $<1 \mathrm{MW}$ \\
Biogas based electricity & $1 \mathrm{MW}$ \\
Total & $50 \mathrm{MW}$ \\
\hline
\end{tabular}

\section{Tectonic \& Geological Settings}

The Neogene (Figure 3) sedimentary sequence penetrated in the Bangladesh part of the Bengal Basin (Figure 4) are represented by alternating beds of sandstones, siltstone, shales and claystones with occasional conglomerate bands of varying thickness. Here, the arenaceous sediments with porosity ranging from 12 to 30 percent of sufficient permeability are the reservoir rocks, while the argillaceous beds will act as cap rock for preventing the loss of geothermal heat from the sandy reservoir beds. The sedimentary column in the Platform Flank as well as the Eastern Folded Belt of Bengal Foredeep attain colossal thickness of about $20 \mathrm{~km}$ as revealed in the aero-magnetic and deep seismic surveys as well as very deep drilling data, (Guha and Bakhtine 1966) as evident in the regional tectonic setting of Bangladesh (Figure 4).

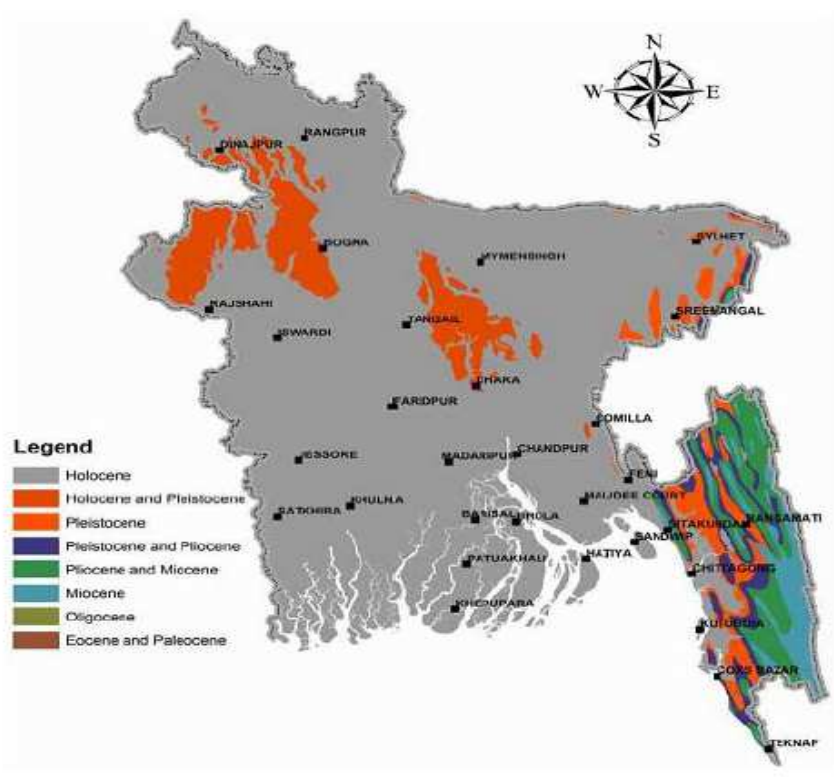

Figure 3. Geological Map of Bangladesh

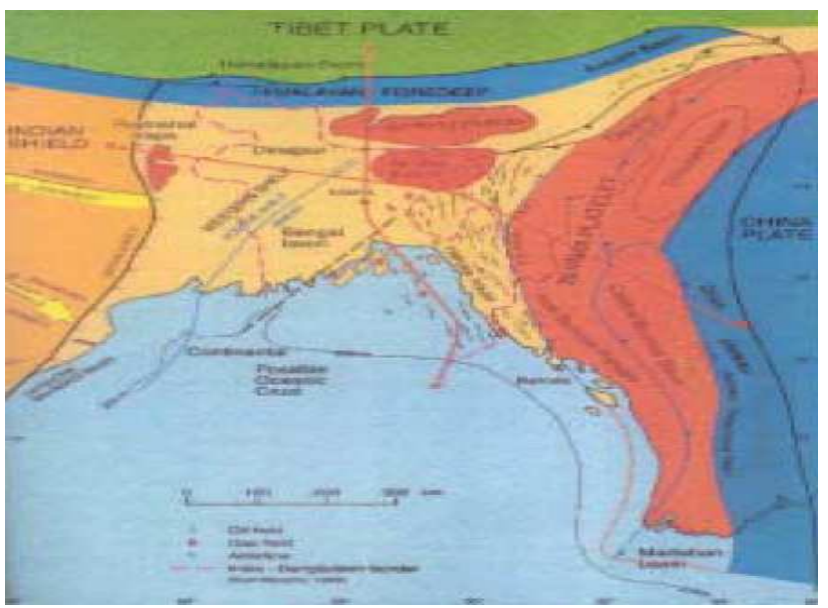

Figure 4. Regional geo tectonic setting of Bangladesh

On the other hand in the shelf area Rangpur Saddle forms the apex of the Garo-Rajmahal Gap where the PreCambriam basement is represented by diorite, granodiorite, granite and pegmatite along with gneisses and schists, which are blanketed by only ca $100 \mathrm{~m}$ of Pliocene Dupi Tila Sandstone, followed by about $10 \mathrm{~m}$ Pliestocene Madhuput Clays and 1 to $3 \mathrm{~m}$ Holocene deposits (Guha 1978). Permian Gondwana coal deposits (sub-bituminous) occur in the shallow faulted basement grabens at a number of places like Barapukuria, Khalashpir, Phulbari, Dighirpar etc. as evident from local small negative gravity anomalies (Petrobangla 1977). The first two underground mines at Barapukuria (coal) and Madhyapara (hard rock) are facing with unforeseen problems of water flooding specially Barapukuria, which upset the target by many years. The fate of the $300 \mathrm{MW}$ thermal power plant at Barapukuria mine head has become uncertain although the infrastructure has already been developed.

From Rangpur Saddle (Figure 5) the basement dips gently first towards north-west along the Dinajpur Slope and then 
steeply towards the Sub - Himalayan Foredeep and the basement attains the depth of $2500 \mathrm{~m}$ at Shalbonhat well located on the north-western most tip of Bangladesh (Tetulia). The basement dips very gently (2 to 3 degrees) towards southeast along the Bogra Slope, as evident in sequence stratigraphy on the surface of the Eocene Sylhet / Bogra Limestone until the Hinge Zone, where dips gets steeper, 15 to 30 degrees (Guha 1978). The Cretaceous Rajmahal Trap formed by upwelling of plastic basalt flow along the fissures at Rajmahal, Bihar (India), is only about $70 \mathrm{~km}$ west of Rajshahi border, which was encountered in deep wells to the east as far as Singra and Kutchma located about $200 \mathrm{~km}$ east of Rajmahal. This basalt trap is known as Sylhet Trap that occurs also in Meghalaya (India). Further east and to the north of Sylhet (Guha 1975), trap occurs which also can be a cap-rock to prevent escape of geothermal energy from the potential reservoir beds. In the Hinge Zone the Ecocene Limestone attains the depth of 8 - 9 $\mathrm{km}$ as can be seen in the seismic profiles.

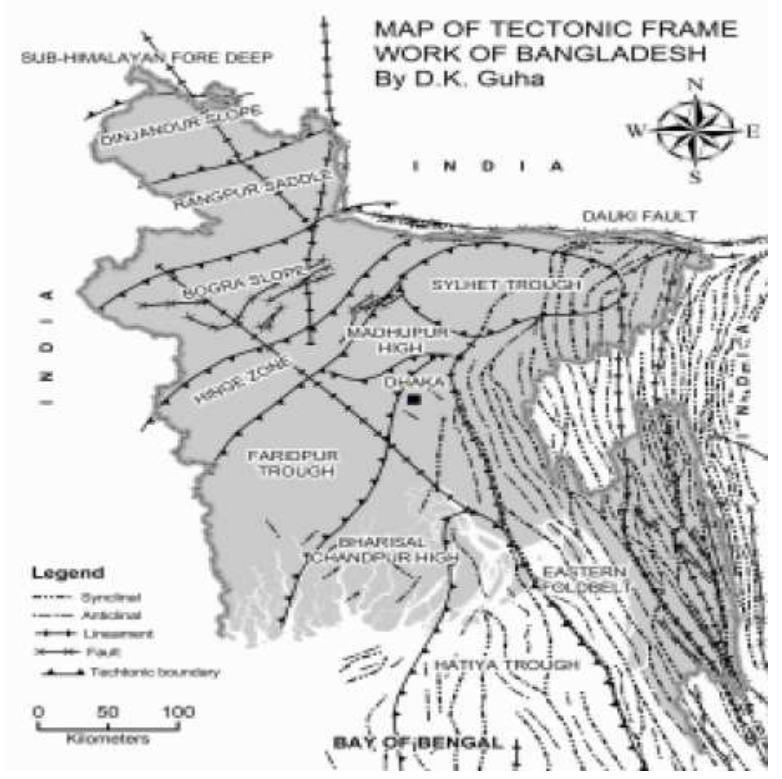

Figure 5. Tectonic framework of Bangladesh with fold axes

\section{Geothermal Energy}

Geothermal energy is the energy contained in the heated rocks and fluid that fills the fractures and pores within the earth's crust. It originates from radioactive decay deep within the Earth and can exist as hot water, steam, or hot dry rocks. Geothermal (meaning "earth heat") energy involves using the high temperatures produced beneath the earth to generate electricity from heated water, as well as for various direct uses (such as hot springs spas, lumber drying or aquaculture). The term geothermal is also applied to the temperatures of the Earth near the surface which are used as a source of consistent temperatures for heating and cooling of buildings. Geothermal applications that involve water heated within the earth are also called hydrothermal processes.
Bangladesh occupies the central part of the Bengal basin, the largest sedimentary basin of the world with thickness of the sedimentary column above the Pre-Cambrian basement of about $20 \mathrm{~km}$ at the axis of the trough The sedimentary column east of the Hinge Zone consists of alternation of porous and permeable sandstones of reasonable thickness with argillaceous clays and shales. The sandstone will be the reservoir for geothermal fluids with sufficient in flow while shales and clays will acts as impervious layers for retaining the geothermal heat within the reservoir for effective use. The Rajmahal / Sylhet Traps of Cretaceous basaltic flows encountered in wells in the Rajshahi Division west of the Hinge Zone will also be a good cap rock for retaining the geothermal energy resources there, as evident elsewhere. A study of Bottom Hole Temperature (BHT) of 13 deep wells drilled for petroleum exploration in northeastern part of Bangladesh show very encouraging results (Khandoker and Haque 1984). The isothermic contours generally follow the Bouguer anomaly map pattern (Petrobangla 1977). The isothermal pattern represents an oval shaped basin with NNE-SSW trend with temperature decreasing from the rim towards the center of the trough. A local high and a low could be seen within the broad trough in the northeast, the high represented by an anticlinal high (Sylhet - Dupi Tila) and low formed by Goyine-Kushiara syncline. The Bouguer anomaly contours vary from -40 mgal in the marginal part to more than $-80 \mathrm{mgal}$ in the central part of the trough. It is evident from the BHT that the geothermal temperature is sufficiently high, 100 to $180{ }^{\circ} \mathrm{C}$, to generate electricity at depth from 3 to $4.5 \mathrm{~km}$ when the geothermal water is taken to the surface through drill holes.

Table 3. Geothermal gradients as noted in some deep wells of Bangladesh

\begin{tabular}{|c|c|c|}
\hline Well Name & Depth $\quad(\mathrm{Km})$ & Gradient $(\mathrm{K} / \mathrm{Km})$ \\
\hline Hazipur & 3,816 & 30,9 \\
\hline Bakhrabad & 12,837 & 25,0 \\
\hline Titas & 13,758 & 30,1 \\
\hline Habigonj & 13,509 & 31,6 \\
\hline Rashidpur & 13,861 & 26,8 \\
\hline Biani Bazar & 14,107 & 28,7 \\
\hline Kailas Tila & 14,139 & 27,8 \\
\hline Sylhet & 12,377 & 31,1 \\
\hline Chhatak & 12,133 & 33,8 \\
\hline Semutang & 14,088 & 30,3 \\
\hline Begamganj & 13,656 & 31,7 \\
\hline
\end{tabular}

\section{Area of Prime Interest}

Recently, the Ministry of Power, Energy and Mineral Resources has approved the establishment of the first ever geothermal power plant (200MW) in the country. A Dhaka based private company named Anglo MGH Energy has initiated this project at Saland of Thakurgaon district. The Rangpur saddle, Bogra shelf potentially offers good 
conditions for geothermal power projects. Although the cost of setting up a geothermal power plant is high due to the high cost of drill-ing wells, it can be reduced by using the abandoned on-shore dry wells which have sufficient high temperature gradient (like over $30 \mathrm{~K} / \mathrm{km}$ ).

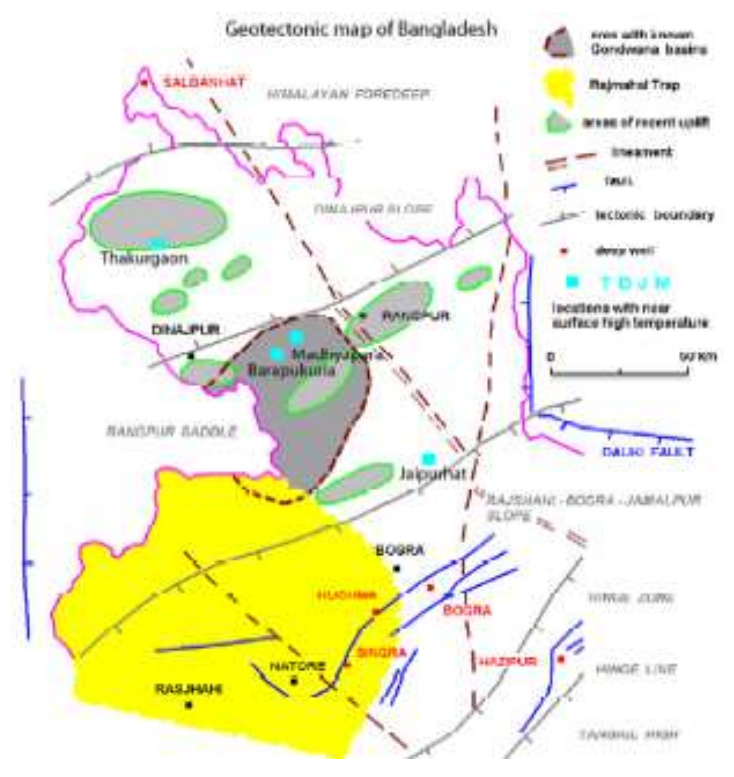

Figure 6. Geotectonic map of northwest Bangladesh

\section{Conclusion}

With the demand for electricity in Bangladesh increasing every day, potential energy sources need to be sought out in order to alleviate the ensuing energy crisis. As Bangladesh is also a developing country, it has to be borne in mind that these energy sources have to be inexpensive, preferably local and can be quickly setup for power generation. Although solar, wind and hydropower offer interesting alternatives they require huge funding, which would strain the economy. This paper looks into the prospect of geothermal energy in Bangladesh and where in the country, there is suitable infrastructure for its implementation. Geothermal power satisfies the criteria for a suitable energy system for Bangladesh, and if our government deploys this energy source, it would be a giant leap forward in solving the present energy crisis of the nation.

\section{Acknowledgements}

Authors are grateful to Prof. Dr. A. K. M. Sadrul Islam, Department of Mechanical \& Chemical Engineering, \& Assistant Professor Syeed Shihav, Department of Electrical \& Electronic Engineering, IUT for helping us in different aspect.

\section{References}

[1] The Climate Institute, "Renewable Energy: Geothermal," http://www.climate.org/2002/topicsgreen/geo.shtml.(Last visited march 17, 2011.)

[2] Debendra K. Guha , Herbert Henkel, Badrul Imam "Geothermal Potential in Bangladesh - Results from Investigations of Abandoned Deep Wells" Published in World Geothermal Congress 2010 Bali, Indonesia, Page(25-29) April 2010.

[3] Khandoker, R.A., and Haque, M. "Temperature Distribution and its Relation to Hydrocarbon Accumulation in Sylhet Trough, Bangladesh", Bangladesh Journal of Geology, (1984).

[4] http://www.bgfcl.org.bd/Daily_Production\%20Reports/Dail y\%20Prod\%20Rep_Opsx\%2017.09.2012.pdf

[5] BOGMC, 1997: Petroleum exploration opportunities in Bangladesh. Bangladesh Oil, Gas and Mineral Corporation (Petrobangla), Dhaka.

[6] Hossain, I., Tsunogae, T., Rajesh, H.M., Chen, B., and Arakawa, Y., 2007: 'Palaeoproterozoic U-Pb SHRIMP zircon age from basement rocks in Bangladesh: a possible remnant of Columbia supercontinent. Comptes Rendus Geosciences, 339, 979-986.

[7] Rahman, M., 2006: Geothermal potential resources in Thakurgaon district, northern Bangladesh. Bangladesh $J$. Geology, 25, 13-30. 